\title{
Science and Environment Education in the Times of the Anthropocene: Some Reflections from India
}

\author{
Aswathy Raveendran and Himanshu Srivastava
}

\begin{abstract}
Anthropocene and the Global South
The word "Anthropocene" is commonly used to denote a geological epoch wherein humans are the central agents driving large-scale and long-lasting environmental changes as manifested in climate change. This chapter uses the term "Anthropocene discourse" to refer to the dominant discourse on the environment and the global environmental crisis and the associated moral and political responsibilities that it places on humankind. Jens Marquardt (2019) points out that this discourse around Anthropocene is West-centric, lending itself to the "ecological modernization" paradigm that emphasizes sustainable development, favoring technological and market solutions to address the ecological crisis. When talking about humankind's collective responsibility in addressing climate justice, it fails to account for the vastly different contributions on the part of the Global North and the Global South in the ecological crisis. Moreover, as Rohan D'Souza (2015) remarks, employing science and technology-based solutions (such as geo-engineering and earth systems science) to the global environmental crisis favors countries of the Global North, which have the advantage of technological know-how and wealth. In another article, situating the notion of the Anthropocene with reference to the history of South Asian environmentalisms, he argues that while
\end{abstract}

A. Raveendran $(\bowtie)$

Department of Humanities and Social Sciences,

Birla Institute of Technology and Science Pilani, Hyderabad, India

H. Srivastava

Homi Bhabha Centre For Science Education, Mumbai, India

(C) The Author(s) 2022

M. F.G. Wallace et al. (eds.), Reimagining Science Education

in the Anthropocene, Palgrave Studies in Education and the Environment, https://doi.org/10.1007/978-3-030-79622-8_12 
most environmentalisms have defined the environmental crisis in relation to resource scarcity, the Anthropocene discourse has emphasized the reduction of greenhouse gas emissions (D'Souza, 2019). He notes that:

the Anthropocene framework profoundly disorients the search for the political and economic drivers that historically spurred radical environmental change in South Asia. Instead of debating the ecological gap or processes of unequal ecological exchange between the developed economies and their erstwhile colonies, Anthropocene futurism pushes for a disconnect between an environmentalism for techno-managerial solutions and one that is devoted to uncovering aspects of historical injustice. (p. 247)

The Anthropocene discourse upholds the notion of sustainable development, according to which economic growth is a non-negotiable for our societies but must not occur at the cost of depletion of natural resources. Sustainable development advocates are optimistic about striking a balance between economic growth and resource utilization through technoscientific innovations. In the next section, we historically situate the sustainable development framework and its construal of the interconnection between environment, development, and technoscience.

\section{ENVIRONMENT-DEVELOPMENT-TECHNOSCIENCE: DEBATES IN INDIA}

In the Western world, the alarm over dwindling natural resources and the necessity to restrain economic growth first appeared in the 1970 s with the publication of the report Limits to Growth in 1972. In the very same year, the United Nations Conference on the Human Environment in Stockholm discussed environment and development as interlinked concepts. This conference was also pivotal in promulgating the idea that economic growth could be achieved without necessarily harming the environment (D'Souza, 2012). The term "sustainable development" was eventually introduced in 1987, in the report Our Common Future, also known as the Brundtland report (D'Souza, 2012; Kothari, 2014). However, it must be noted that the 1970s also witnessed the emergence of modern environmentalism in the Western world with the publication of Rachel Carson's Silent Spring.

The policies of the Indian government responded to these international developments, which is evident in the discursive shifts in the understanding of nature and economic growth in the first to the fifth five-year plan of the planning commission of the Indian government. While the first five-year plan document of independent India discusses both nature and human beings in terms of untapped potential, the notion of resource scarcity and the necessity to acknowledge environmental degradation and pollution are discernible in the fifth plan document (D'Souza, 2012). The shift in the discourse on nature and economic growth also parallels a global discursive shift in the understanding 
of development, which was conceptualized only in terms of economic growth in the 1800s to an understanding of development as growth that is inclusive of social and environmental indicators (Achuthan, 2011).

The discourses on development in postcolonial India are also important to understand in relation to the visions of three nationalist leaders-Jawaharlal Nehru, M. K. Gandhi, and B. R. Ambedkar. The development model adopted by the Indian state post-independence was inspired by Nehru's scientific socialism, which advocated that controlled economic growth under a socialist state, bolstered by technoscience-based development projects, would save a country struggling to overcome poverty, ill-health, and overpopulation. On the other hand, Gandhi had an entirely different vision of development that sought to sustain rural livelihoods, opposed large deskilling technology and industrialization, and emphasized decentralized governance through the village panchayats (decentralized governance at the village level). Ambedkar, a scholar, anti-caste leader, and the architect of the Indian constitution, emphasized the necessity of state-protected industrialization (Robinson, 2014). His concerns were primarily to protect the people of the marginalized castes. He staunchly believed that industrialization, through the provision of employment opportunities, would put an end to caste-based economic feudal relations prevalent in the primarily agrarian Indian society (Shivaprasad, 2016).

Despite these diverse visions, the Nehruvian imagination of scientific socialism prevailed when Jawaharlal Nehru took over as the first prime minister of independent India. Large technoscientific development projects, such as the atomic energy ventures of the 1950s, the Green Revolution of the 1960s and 1970s, and the White Revolution of dairy technologies of the 1970s and 1980s, were instituted in this period. In these decades, however, people's movements also began to raise critical questions about these technoscientific development projects-whom they benefit and whom they leave behind. For instance, the Narmada Bachao Aandolan (Save Narmada Movement) of the 1980s was a resilient movement against the Sardar Sarovar hydroelectric power-plant, a big technoscientific development project, raising valid concerns about widespread ecological destruction as well as displacement of the marginalized people who lived near the project site. Thus, the people's movements directly raised critical questions about development-development for whom and at what cost? In other words, while international and national policy documents celebrated sustainable development, people's movements in India through the 1970s and 1980s stressed the political nature of environmental issues, seeking to politicize the notion of development and raising questions on conventional models of economic growth.

Since the 1990s, with the advent of liberalization, the Indian economy opened up to foreign investment, culminating in the integration of the Indian economy with the global economy. Concomitantly, the Indian state receded from investing in essential welfare services such as health and education, resulting in the increased privatization of these sectors. At present, the Indian government has also relaxed environmental laws to favor the private sector. For 
instance, very recently, laws that protect Indigenous communities that depend on the forests for survival and livelihood were relaxed (Aggarwal, 2019).

In academia, the 1990s also witnessed the emergence of the postdevelopment (PD) discourses (Escobar, 2011). Drawing on post-structuralist theorists such as Foucault, proponents of PD discourses argue that development and its associated terminology need to be understood as a dominant discourse and that this discourse that emerged in the Global North seeks to define, limit, and exploit the Global South. However, critics of the post-development discourse argue that development is not a monolithic, allpowerful entity. The Global South has resisted the development discourse through "local re-imaginations, alternative voices, and different worldviews" (D’Souza, 2012, p. 8).

The Nehruvian vision for postcolonial India forged a strong relationship between science, technology, and development, and therefore, the sustainable development framework has a stronghold in the Indian policy and educational discourse. For these reasons, we argue that it is necessary to dismantle the Anthropocene discourse and work toward transformative educational agendas. More specifically, this translates to: (1) examining the curriculum for how the Anthropocene discourse manifests itself, (2) understanding how the Anthropocene discourse shapes student subjectivities, and (3) working with students to reimagine alternatives that resist or subvert the Anthropocene discourse. Having set the context, in the next section, we switch to a conversational format to discuss what our respective research reveals about the nature of discourses around the environmental crisis, development, and technology in science and environment education.

\section{Educational Discourse on Development and EnVironment}

Aswathy: I will begin by locating myself and my research. I was born and raised in an upper-caste, middle-class family in the south Indian state of Kerala, well-known for its long history of communist politics and its relative prosperity. Religion-based communal tensions are also less pronounced in Kerala than the rest of the country, despite a sizeable minority population constituting Muslims and Christians. Perhaps because of Kerala's uniqueness about the aspects mentioned above and my caste and class privilege, I grew up somewhat oblivious to structural inequalities related to caste and class. However, I faced the full brunt of the misogyny and sexism endemic to Kerala's society in my teen years in the 1990s, when India opened up to the global economy.

After completing my schooling in Kerala, I went on to do undergraduate and master's degrees in biotechnology, after which I switched to science education research. My journey into critical science education research was the culmination of a series of unpleasant experiences with biotechnology research (Raveendran, 2019). Through science education research, I sought to make sense of these experiences and make positive changes to the field that had failed 
me but had not defeated me. I soon came to realize that science education research offered exciting possibilities to humanize and politicize the natural sciences.

Himanshu: I belong to Kanpur, a crowded city in Northern India, also known to be the industrial hub of the state of Uttar Pradesh, and according to the World Health Organization, the most polluted city in the world in 2018. Kanpur is home to millions of working-class people who migrate from various parts of the country searching for a livelihood. Caste- and religion-based politics have a long history in that region and conflicts between upper-caste Hindus, Muslims, and Dalits are common. Born in a working-class family, I spent my childhood in a neighborhood watching unemployed youth whiling away their time playing street cricket, betting, and fighting. After completing my school education, I got admitted to a prestigious and highly competitive engineering college. However, as a student, I soon began to feel a sense of disengagement with the engineering curriculum, which was depoliticized and disconnected from real life. As part of a voluntary student organization, I spent a significant amount of time with underprivileged children of the locality, helping them with their school education. My engagement with education deepened further when I got an opportunity to work with a non-profit organization in Central India and pursued educational research. In retrospect, I feel that my entry into critical science education was inevitable given my science and technology background and a broader interest in sociopolitical issues.

Aswathy: Now that we have both described what we are about, let's return to the theme of this chapter. At the outset, I think it is important to state that formal science education practices and research in India are steeped in positivism, in terms of restricting its content to disciplinary concerns and marginalising sociopolitical concerns (Raveendran \& Chunawala, 2013). Moreover, the textbooks also reveal a commitment to Nehruvian scientific socialism, which forges a link between science, technology, and socioeconomic development. Since both of us have done our fair share of analyzing textbook discourses, perhaps we could discuss this a bit?

Himanshu: I will try to respond to this through a discussion of my doctoral work. My primary interest has been to critically examine the discourse on environment and technoscientific development in the school curriculum and explore the ideological commitments of science and environmental studies (EVS) textbooks. As you know, in our context, the mandate is to institute compulsory environment education until grade 12 , and this needs to be systematically infused into the curricula of all disciplines (NCERT, 2006b). In practice, however, the significant burden of teaching environment-related topics falls on the science teachers, as they are perceived to be more equipped to deal with the subject.

Aswathy: Where best to insert techno-managerial solutions to the environmental crisis other than the science textbooks!

Himanshu: Yes, and the EVS and science textbooks that I have analyzed do reveal an overarching techno-managerial orientation. In all the textbooks 
(class 4 to class 10) of the Maharashtra state board, what defines development is the advancement in transport, communication and space technology, big dams, and factories. Occasional references to "welfare" issues such as food security, sanitation, access to water, child labor, and prevalence of superstitions in society exist in the junior classes, but at more advanced levels, the textbooks are quite brazen about pushing the technoscientific model of development. Even the widely criticised Green Revolution is discussed with much optimism!

Aswathy: This has to do with the fact that the curricular emphasis at this stage is disciplinary. In my analysis of science, technology, and society (STS) issues in class 11 and 12 biology textbooks, ${ }^{1}$ I noticed that the STS themes are treated in a lackadaisical manner, with very little consistency in the discussion of ethico-political positions across topics. The chapter on environmental issues is of particular interest with its strong techno-managerial focus. For every "environmental issue" discussed in the chapter, there is a proposed technical solution. Even more interesting is the chapter on ecosystems, where the value of natural ecosystems is discussed in the language of economics (Raveendran, 2017).

Himanshu: In my analysis of textbooks too, I find nature conceptualized merely as a "resource"-whether it is land, water, ocean, forests, plants, or animals. This objectification of nature reveals the commodifying tendencies of the economy. Also, the perspective of looking at nature is anthropocentric. Plants, animals, and even microbes are discussed in terms of the useful/harmful binary, as if their lives do not have any other value.

Aswathy: The class 12 biology textbook also discusses the ecosystem in terms of "services," revealing similar anthropocentric tendencies. The class 12 textbook also upholds neo-Malthusian ideologies. For instance, in a chapter on reproductive health, overpopulation is constructed as a burning problem, even when we now have evidence that the fertility rates have declined. Other chapters also advance the population bomb thesis to discuss the environmental crisis and the necessity to enhance food production.

Himanshu: Apart from the Malthusian argument, which posits overpopulation as the root cause of the environmental crisis, some other explanations that are offered by textbooks are people's attitudes toward the environment, lack of awareness, and overexploitation of resources. What is striking to me is the total lack of acknowledgement of differential access and consumption of resources in a highly stratified society like ours. The structural roots of the

\footnotetext{
${ }^{1}$ Education is part of the concurrent list of the constitution of India. This effectively translates to both the central government and all the state governments being responsible for designing, developing, and implementing curriculum at the school level. The biology textbooks that were analyzed were developed by the National Council of Education, Research and Training (NCERT), an apex body responsible for textbook development. The NCERT textbooks are followed in all the schools governed by the central government. However, each state in India has a State Council of Education, Research and Training (SCERT). The textbooks developed by various SCERTs are referred to as the state board textbooks. These textbooks are followed in all the schools affiliated with the state board with no exception.
} 
environmental crisis, such as the profit-oriented nature of economic growth, rapid industrialization, and urbanization, are mentioned only in passing. The measures that are suggested to overcome the situation also reflect the same psyche. Population control, changing people's attitudes, proper management of natural resources, and increasing awareness among people are suggested as solutions in these textbooks - solutions that are managerial, individualistic, and technocratic, reflecting the presence of an eco-capitalist ideology. These findings are consistent with another study that I had carried out in the schools of Madhya Pradesh to examine the environmental philosophies underpinning the teaching of environmental issues (Haydock \& Srivastava, 2019).

We pause this conversation briefly here. Textbooks are an essential part of the teaching-learning process in India. Textbook discourses are powerful since they seek to define and limit what can be legitimately articulated and conceived of any topic. Do they speak to everyone the same way? What impacts do the textbook discourses have on their subjects? How do subjectivities get constituted in relation to the textbook discourses? These are difficult questions that educationists in various settings have attempted to answer (see, for example, Bazzul, 2013). Apart from the textbooks, the learners' physical and cultural environment and the broader politico-economic context within which their lives are embedded would also shape their subjectivities, as manifested in their values, attitudes, and aspirations. In the next section, we seek to discuss how student subjectivities are shaped by the Anthropocene discourse.

\section{Students' Values and Aspirations}

Himanshu: Let me begin with another part of my research in which I interacted with the children of marginalised communities of the $M$ (East) ward ${ }^{2}$ area in Mumbai in out-of-school settings. Part of this interaction focused on their aspirations, attitudes towards environment and development, and political literacy. I also looked at their textbooks and observed classroom teaching in the region. What I gathered from a critical discourse analysis of their textbooks, classroom teaching practices, and my direct interactions with the students is that the school education does not adequately address the lived realities, questions, and concerns of the marginalised communities.

Aswathy: I am not entirely surprised by this finding. I would say that this has more to do with the centralized system of textbook production in India. Could these textbooks ever address the diverse micro-realities of a multicultural country?

2 The M(East) ward in Mumbai is the most neglected ward of the city, with a Human Development Index being merely 0.05. The ward hosts one of Asia's largest landfill sitesDeonar dumping ground, an incineration plant, a slaughterhouse, and oil refineries, as well as a couple of fertilizer plants. Life expectancy at the time of birth in this ward is a mere 39.4 years, which is 30 years less than the national average. 
Himanshu: Probably not. The textbooks have to cater to a highly diverse set of learners, but I believe that the teachers can make the necessary connections to the learners' contexts, through a critical and resistant reading of textbooks (Apple, 1992), and if they have to achieve this, they will need to understand what these students are about.

Aswathy: Let me cut to a very different context that I am familiar with. An elite engineering institute with a $100 \%$ job placement record. Students who attend this engineering college are from well-off backgrounds. I refer to this context because I too am trying to understand what these students are abouthow they have come to embody their neoliberal middle-class subjectivities (Türken et al., 2016) and how they fashion themselves into autonomous, individualised, rational, and entrepreneurial selves, seemingly disconnected from the wider world.

Himanshu: Our contexts are not completely disconnected from one another. The respective student groups that we work with represent two ends of the socioeconomic spectrum. While the students living close to the landfill site face the brunt of the careless production-consumption cycle in terms of severe health and environmental impacts, the student group that you work with will drive the economy, since they will occupy techno-managerial positions in the future. They will drive the innovations that will both destroy and purportedly save the world.

Aswathy: ... and what is even more interesting is that both these groups of students share similar aspirations.

Himanshu: Yes, in my conversations with a few adolescents of the M(East) ward, every single one of them unanimously expressed their wish to become engineers - these aspirations also matched with their parents' dreams for them. I recall a parent mentioning once that he would like his child to achieve what he could not achieve for himself. Under no circumstance did he want his child to come back to the same "shit-hole."

Aswathy: This throws open a conundrum-can we fault these students' aspirations, given the conditions in which they live? If becoming engineers and having access to a particular lifestyle is not something these students have experienced, how can we, as educators, deny them that aspiration? What would a transformative science and environmental education mean in this context?

Himanshu: There is no simple answer. But I think, for the M(East) ward students, critical discussions on the living and working conditions of the people in their community are necessary. When I attempted to do this through focus group discussions, one thing that struck me was the shame and humiliation they harbor about who they are and where they come from. I remember a session where I presented some data on the life expectancy in the M(East) ward, which is a mere 39.4 years. They were in denial of it. I also noticed a similar embarrassment when I tried to elicit some discussion on their personal backgrounds. Some of their family members were rag pickers, and they were reluctant to discuss that. 
Aswathy: Maybe our task is to facilitate the transformation of these emotions of shame and humiliation to indignation. However, indignation alone cannot be an endpoint because once the students realize that very little can be done to transform their living realities in the short run, frustration would inevitably set in.

Himanshu: I did notice that there were seeds of indignation in some of the students. The groups that I interacted with were surprisingly quite politically aware. Thus, I am not sure if we can be pessimistic about transformative possibilities. Change is bound to take time. In the context of the $M$ (East) ward, there are a few non-governmental organizations, workers' unions, and academics working with people of all age groups - these groups are working on an array of issues, ranging from health and education to the organization of workers. One way forward may be for educators to work with these groups over a more extended period. Transformation cannot happen overnight, and it has to be a sustained effort with a focus on acquiring critical understanding, developing solidarities, and organised, collective action.

Aswathy: Yes, maybe the way forward, as you suggest, is sustained effort in conjunction with other groups. My concerns have revolved around how to work with the privileged student groups. Engaging with this group is also very important-given the fact that they will, in the future, occupy technomanagerial positions and drive the economy. I work with the Department of Humanities and Social Sciences (HSS) in a private engineering institute. As a critical science educator working in this space, it is hard to ignore the fact that engineering practices and education are strongly embedded within the global neoliberal economy. This is evident in how the educational system is structured, the kind of employment opportunities that present themselves to students, and most so in the consumerist lifestyles that they inevitably embrace. Our primary task, as HSS faculty, is to teach "soft" skills such as language skills, personality development, and values to engineering undergraduates. While there are courses that have incorporated elements of critical, Marxist, feminist, and post-structural theory, these are elective subjects, and given the fact that the students that we cater to are gearing to be future technologists, they attribute the least value to the HSS courses. Very few students appreciate courses that introduce critical theory or adopt Marxist/leftist ideological positions.

Himanshu: Probably, this has to do with the numbness towards the harsh social reality that they have come to accept unconditionally.

Aswathy: Yes, a certain kind of numbness or indifference. And, the question is-how does one puncture that? These young people have seen poverty around them, although they have never experienced it firsthand because of their class and caste privilege and, therefore, fail to register it. Our country's social inequality is so stark that two people, even living fifty feet apart from one another, would experience completely different social and physical realities. For example, a person's life in a high-rise would be starkly different from that of a person in a slum a few feet away. However, social consciousness 
(structured by caste and class) has evolved so that these two human beings would go through life without being severely affected by one another, only, at the most, developing a transactional relationship. I remember a discussion in one of my classrooms where a group of three middle-class girls discussed whether their bais (female domestic help) fell ill or not! (Raveendran, 2020).

Himanshu: I find it interesting that you distinguish between social and physical environments. It is also striking that students experience alienation within their social and physical environments, wherein they feel disconnected from each other and their physical environments. I want to focus a little bit on the latter-on the physical environment. While working with students from marginalized communities at the $\mathrm{M}$ (East) ward, I have often wondered what developing a connection to the physical environment means in such highly degraded urban environments. For instance, when I would attempt to discuss waste and sanitation (what was salient for me about their context), they would not want to discuss that at length.

Aswathy: What if we begin with what they like about their lived environments? To people like us, from relatively privileged backgrounds, what stands out the most about these children's settings is the filth and the waste. However, as educators, it might be worthwhile to work on consolidating and affirming their positive experiences of their environment as well.

Himanshu: That might be a possible way forward, and I have also been thinking along these lines. Environmental education initiatives that seek to establish pro-environmental attitudes through hands-on farming, composting, gardening, etc. do exist in India. Though some exploratory studies (Dutta \& Chandrasekharan, 2018) suggest that these activities lead to the development of pro-environmental values in some of the participants, there needs to be a rigorous evaluation of whether the compassion and connection with "nature" extend beyond these built environments (gardens, farms etc.). After all, interventions that use built environments package and present "nature" to participants in a certain way, as thriving, flourishing, enchanting, and clean. The question that I find myself asking is-are there ways to tap into and validate experiences or feelings of connection that children of marginalized communities have with what-in our sanitized perception-is "degraded," "filthy," "unclean" landscapes, which are home to them? This does not mean that we ignore the physical dangers in these spaces-the illnesses, the pollution, the harmful and unpleasant odors. But we often tend to focus only on unpleasant experiences. Probably, a starting point could be to build on the sense of relatedness that these children have to their environments and other people in their communities.

Aswathy: Working with the privileged will be more challenging. How do we get them to question their privileges and develop a sense of empathy with the marginalized and their physical environments? More importantly, how do we convince them that developing these sensibilities is essential? 


\section{Concluding Thoughts}

India's environmental movement has combined ecological concerns with class and caste politics (Guha \& Martinez-Alier, 2013; Kumar, 2016). It is pertinent that transformative science and environmental education in India that is critical of the Anthropocene discourse incorporate these concerns. Our examination of textbooks reveals that the textbooks support sustainable development and the ecological modernization paradigm. Interactions with student groups of different socioeconomic backgrounds also suggest that their subjectivities, as manifested in their values and aspirations, are shaped by the Anthropocene discourse. In our conversation, it emerged that working with both the marginalized and the privileged is necessary. More importantly, we realize that working with their emotions is an essential step toward their politicization, which resonates with other science education researchers' views. For instance, referring to Claudia Ruitenberg, Ralph Levinson (2010) argues that political emotions are distinct from personal insults or feelings of moral outrage. The former entails feeling a sense of anger on behalf of groups less privileged than one's group. Similarly, drawing on the scholarship of bell hooks, Antonio Negri, and Michael Hardt, Bazzul, and Tolbert (2019) argue for the necessity for political love to underpin our critical and transformative educational agendas. They write:

political love is pursued in the name of collective joy—a refusal of the politics of domination and a recognition that other worlds in common are possible. Love is pedagogical; and so how can we learn to love each other better? How can we learn to extend our love beyond love of self/extensions of self (e.g., our own genetic families) toward a love of/for/with the multitude? (p. 306)

The challenge for educators working with marginalized communities is to find ways to inculcate political emotions that have the power to alter their living conditions. While working with marginalized groups of students living in ecological degradation sites, it might be important to validate their sense of community and their positive relationships with their physical environments. Transformative pedagogical practices involving privileged groups of students would entail getting them to understand how their career choices, lifestyles, and the broader neoliberal power structures are implicated in the sociopolitical and ecological crisis that we are faced with. Undoing privilege is a difficult task, but is a worthwhile goal to aspire for.

\section{REFERENCES}

Achuthan, A. (2011). Re:wiring bodies. Bangalore: The Centre for Internet \& Society. Aggarwal, M. (2019, May 25). What Modi and BJP's return means for environmental laws in India. HuffPost. https://www.huffingtonpost.in/entry/modi-green-lawsenvironment_in_5ce7dbale4b0a2f9f28d7cc4? guccounter=1. 
Apple, M. W. (1992). The text and cultural politics. Educational Researcher, 21(7), 4-19.

Bazzul, J. (2013). How discourses of biology textbooks work to constitute subjectivity: From the ethical to the colonial (Doctoral dissertation). https://tspace.library.uto ronto.ca/bitstream/1807/43477/6/Bazzul_Jesse_T_201311_PhD_Thesis.pdf.

Bazzul, J., \& Tolbert, S. (2019). Love, politics and science education on a damaged planet. Cultural Studies of Science Education, 14(2), 303-308.

D'Souza, R. (2012). Introduction. In D'Souza (Ed.), Environment, technology and development: Critical and subversive essays (pp. 1-16). Orient Blackswan.

D'Souza, R. (2015). Nations without borders: Climate security and the south in the epoch of the Anthropocene. Strategic Analysis, 39(6), 720-728.

D'Souza, R. (2019). Environmentalism and the politics of preemption: Reconsidering South Asia's environmental history in the epoch of the Anthropocene. Geoforum, 101, 242-249.

Dutta, D., \& Chandrasekharan, S. (2018). Doing to being: Farming actions in a community coalesce into pro-environment motivations and values. Environmental Education Research, 24(8), 1192-1210.

Escobar, A. (2011). Encountering development: The making and unmaking of the Third World. Princeton University Press.

Guha, R., \& Alier, J. M. (2013). Varieties of environmentalism: Essays north and south. Routledge.

Haydock, K., \& Srivastava, H. (2019). Environmental philosophies underlying the teaching of environmental education: A case study in India. Environmental Education Research, 25(7), 1038-1065.

Kothari, A. (2014). Radical ecological democracy: A path forward for India and beyond. Development, 57(1), 36-45.

Kumar, V. R. (2016). History of Indian environmental movement: A study of Dr. B. R. Ambedkar from the perspective of access to water. Contemporary Voice of Dalit, $8(2), 239-245$.

Levinson, R. (2010). Science education and democratic participation: An uneasy congruence? Studies in Science Education, 46(1), 69-119.

Marquardt, J. (2019). Worlds apart? The Global South and the Anthropocene. In T. Hickman, L. Partzsch, P. Pattberg, \& S. Weiland (Eds.), The Anthropocene debate and political science (pp. 200-218). Routledge.

NCERT. (2006a). Biology: Textbook for Class XII. National Council of Educational Research and Training (NCERT).

NCERT. (2006b). Position Paper, National Focus Group on Habitat and Learning. National Council of Educational Research and Training (NCERT).

Raveendran, A. (2017). Conceptualizing critical science education using socioscientific issues (Unpublished doctoral dissertation). Tata Institute of Fundamental Research Mumbai.

Raveendran, A. (2019). Finding a critical voice. In J. Bazzul \& C. Siry (Eds.), Critical voices in science education research (pp. 27-36). Springer.

Raveendran, A. (2020). Invoking the political in socioscientific issues: A study of Indian students' discussions on commercial surrogacy. Science Education. https:// doi.org/10.1002/sce.21601.

Raveendran, A., \& Chunawala, S. (2013). Towards an understanding of socioscientific issues as means to achieve critical scientific literacy. In G. Nagarjuna, A. Jamakhandi, \& E. Sam (Eds.), Proceedings of epiSTEME 5 International 
Conference to Review Research on Science, Technology and Mathematics Education (pp. 67-73). Cinnamonteal. http://episteme.hbcse.tifr.res.in/index.php/episte me5/5/paper/view/130/13.

Robinson, R. (2014). Planning and economic development: Ambedkar versus Gandhi. In B. Pati (Ed.), Invoking Ambedkar: Contributions, receptions, legacies (pp. 59-71). Primus books.

Shivaprasad, E. (2016). Ambedkar's perceptions of development an empirical study in Mysore District (Unpublished doctoral thesis, University of Mysore, Mysore, India). https://shodhganga.inflibnet.ac.in/handle/10603/145202.

Türken, S., Nafstad, H. E., Blakar, R. M., \& Roen, K. (2016). Making sense of neoliberal subjectivity: A discourse analysis of media language on self-development. Globalizations, 13(1), 32-46.

Open Access This chapter is licensed under the terms of the Creative Commons Attribution 4.0 International License (http://creativecommons.org/licenses/by/4.0/), which permits use, sharing, adaptation, distribution and reproduction in any medium or format, as long as you give appropriate credit to the original author(s) and the source, provide a link to the Creative Commons license and indicate if changes were made.

The images or other third party material in this chapter are included in the chapter's Creative Commons license, unless indicated otherwise in a credit line to the material. If material is not included in the chapter's Creative Commons license and your intended use is not permitted by statutory regulation or exceeds the permitted use, you will need to obtain permission directly from the copyright holder.

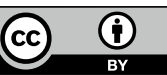

